\title{
Management Strategy for China's Internet Media Industry
}

\author{
Xiao Zhou \\ Journalism School, Fudan University, China
}

Copyright@2017 by authors, all rights reserved. Authors agree that this article remains permanently open access under the terms of the Creative Commons Attribution License 4.0 International License

\begin{abstract}
Introduce: 2015 became a significant landmark for new media industry development globally, especially in China. Tencent has become the China's largest media platform, just as that Facebook has become the first big user entry of American news media. We need change our way to think about and use those social media platform. First of all, we need understand the evolution of our economy system brought by new media. Methodology: This article uses the SCP (structure - conduct - performance) model to analyze the cross overlap areas between China's top 100 internet enterprises and China's capital markets. And author creates a $4 \times 4$ matrix tool with 16 interactive communication modes to analyze the changing path of user preference on digital social platform from $\mathrm{C} 2 \mathrm{C}$ to $\mathrm{S} 2 \mathrm{~S}$ mode as its internal logic. Results: This article finds two important changes of China's new media industry and proposes some systematic, reasonable and feasible management strategy: First is the comprehensive platform developing tendency. Second is the growing expanding investment merger accelerates the cross-shareholdings and strategic cooperation between platform type enterprises, and help the small micro content enterprises creating a large "long tail"; Those two changes indicates that highly commercialized Chinese Internet media industry is speeding its monopoly scale, which reflects that the worldwide digital network lacks proper grass-roots management framework and multi-win interest coordination mechanism. So the most important management strategy for China's internet media industry is to build a globalized coordinating system that based on both self-control and regulations. In order to sustainably benefit individuals, countries, and business, and form a community of interests between them, we need to change the present situation of privacy protection, where individuals, countries, and enterprises stand against each other, comprehensively protect privacy, and maintain internet security use with the faith of "serve under the people" as its top priority.
\end{abstract}

Keywords Comprehensive, Social Platform, Media Industry, China

\section{The Definition for New Media Industry}

2015 became a significant landmark for new media industry development globally. Tencent has become the China's largest media platform with the comprehensive advantages of traffic, users scale and content innovation. Meanwhile, Facebook has become the first big entry of American news media based on its strategic cooperation with 9 famous content provider including NBC and New York Times, etc.

Those parts are not included in this chapter which hasn't yet constructed a comprehensive internet platform or hasn't very clear market main body. That's why so many state-owned media organizations and their subsidiaries are not included here.

When "I" as the demander who standing right in front of the supplier, the new highly personalized and customized economic world would come closer and the outdated value standard and industry system lacking personalized and humanized would go away and vanish. This also means that when every person benefits for themselves and others, they are doing something useful and helpful to promote technical society autonomy at the same time. It inevitably bring the economic reform to political reform and cultural reform, those three synchronized reforms and restructures will lead to 'person-to-person economy', 'person-to-person politics' and 'person-to-person society'.

New media industry just based on such socialized platform as its core, creates millions or billions of global users by providing large scale of social value. With such large scale of users, so many tiny niche markets are coming out under the long tail effect to meet the highly personalized needs, to innovative business models and to gain business interests. In other words, there is no ability to create large scale platforms and to provide social value, there is no hope to develop any commercial vitality and commercial gains on the long tail market. Social value provided by the new media industry is very important, because it draws the following two significant boundaries: 
First, the social value makes itself an indispensable precondition for commercial value based on a new rule of increasing marginal benefit. It's a revolutionary for traditional economic world based on diminishing marginal benefit, which marks the success of the new platform economic;

Second, the social value provides the rationality for the super scale monopoly of new media industry platform only if they can supply social value more than economic value under any practicable quantitative standard.

Just because of this, this article uses the SCP (structure conduct - performance) analysis model and chooses the top 20 listed companies as samples from China's top 100 internet enterprises and China's capital markets. We select the Chinese Internet enterprise 100 strong correlation with the media industry in the top 20 as sample to analyze the major structure, behavior characteristics and the performance of China's new media industry systematically.

New media industries in this article is constructed by the software or hardware technology developers, content providers and digital network operators who directly owned or directly attached to the first user entries, as well as their products and services, and the whole complicated market with super large scale of users and online communities. Those are all based on the digital intelligent network, supported by 'point to point' interactive communication model and social platform as value-added power. They achieve survival and gain profits from two-sides market and platform economics [1].

The first entry refers to the first interface user contact or broadcast any information online, not only with the higher operating frequency but also with the fundamental function of guiding users to other information entrance or interface. It may be an application or website, such as WeChat, Facebook, Baidu or Google. It could also be an intelligent hardware with perfect fusion of content and software, such as iPhone or Google glasses, Le TV driverless cars or Huawei drone. Furthermore, new media industry is not limited to any legal institutions and anyone could be involved in only if meeting the above definition no matter organizations such as content providers, software or hardware developers and operators, or individual natural person.

\section{The General Situation and Trend of China's New Media Industry}

The following internet open market leading companies represent the world that has user first entry in the new media industry as most important platform type enterprises. They determine the global big pattern of the new media industry.

Table 1. 2015-2016 The global Internet public market leader (listed company)

\begin{tabular}{|c|c|c|c|c|}
\hline Rank & Company & Region & 2015 Market Value (SB) & 2014 Revenue (SMM) \\
\hline 1 & Apple & USA & $\$ 764$ & $\$ 199,800$ \\
\hline 2 & Google & USA & 373 & 66,001 \\
\hline 3 & Alibaba & China & 233 & 11,417 \\
\hline 4 & Facebook & USA & 226 & 12,466 \\
\hline 5 & Amazon & USA & 199 & 88,988 \\
\hline 6 & Tencent & China & 190 & 12,727 \\
\hline 7 & eBay & USA & 73 & 17,902 \\
\hline 8 & Baidu & China & 72 & 7,909 \\
\hline 9 & Priceline & USA & 63 & 8,442 \\
\hline 10 & Salesforce.com & USA & 49 & 5,374 \\
\hline 11 & JD.com & China & 48 & 18,543 \\
\hline 12 & Yahoo! & USA & 41 & 4,618 \\
\hline 13 & Netflix & USA & 38 & 5,505 \\
\hline 14 & Linkedin & USA & 25 & 2,219 \\
\hline 15 & Twitter & USA & 24 & 1,403 \\
\hline 16 & Yahoo! Japan & Japan & 23 & 3,441 \\
\hline 17 & Rakuten & Japan & 23 & 4,996 \\
\hline 18 & NetEase & China & 19 & 1,889 \\
\hline 19 & Naver & Korea & 17 & 2,527 \\
\hline 20 & Vipshop & China & 15 & 3,774 \\
\hline Total & & & $\$ 2,513$ & $\$ 479,939$ \\
\hline
\end{tabular}

These enterprises concentrated distribution in China, the United States, Japan and South Korea. Among them, according to the index of market value in 2015 and revenue in 2014, the U.S. internet companies occupy 55\% of the world's top 20 enterprises, China's Ali, Jingdong, Netease, Tencent, Baidu and Vipshop occupy 30\%, and the other 15\% companies belong to Japan and South Korean.

Let's start with the following two graphs to gain an intuitive understanding of the general situation and trend of China's new media industry from the global view during 2015 to 2016. 
Table 2. 2015-2016 The global pattern of the new media industry

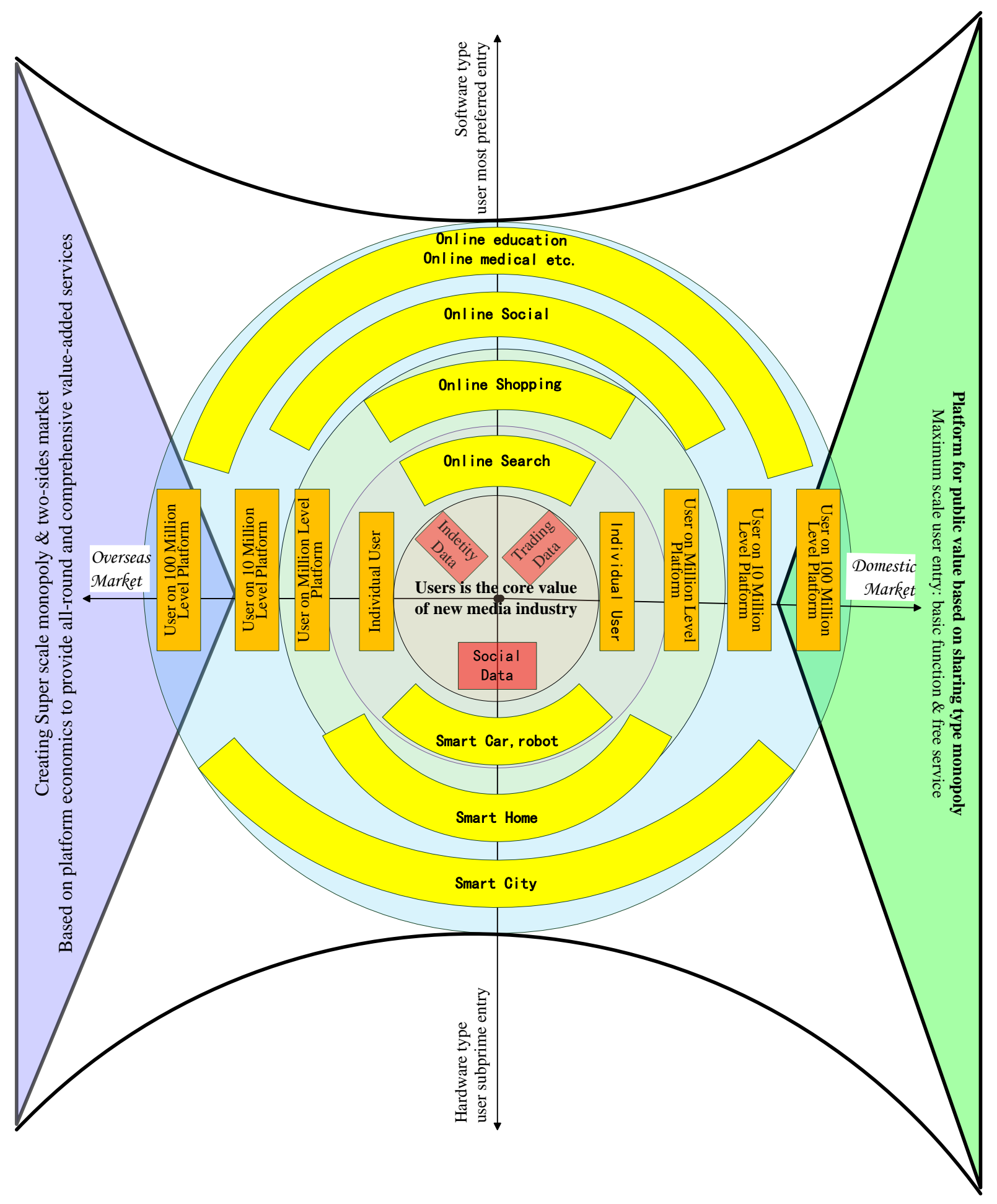

Source: the author self-drawing

Table 2 explains the new pattern of the media industry, taking the social media platform as the core and the point-to-point communication model as foundation.

The first central circle area indicates that internet users has become the core value new media industry. The light blue concentric circles layered extending outward from the central area represents different levels of user platform scale from million, 10 million to 100 million respectively. On its right side is domestic home market, and the left side is the international market. The green triangular region connected to 100 million level user platform on the right side of the domestic market represents the maximized user entry based on social public value. It upward points to the software-type user first entry made 
by the circles of online search, online shopping, online social, online education and online medical. And it downward points to the hardware-type user secondary entry made by the circles of smart car, smart robot, smart home and smart city. The blue triangular region connected to 100 million level user platform on the left side of the international market represents the successful construction of international platform economics and two-sides market to break through the limitation of local market and to provide comprehensive value-added service. Two curves bowing to the central point from up and down form a narrow waist area. It represents industry bottlenecks of pioneering technology and content innovation.

Table 3. General situation and trend of Chinese new media industry in 2016

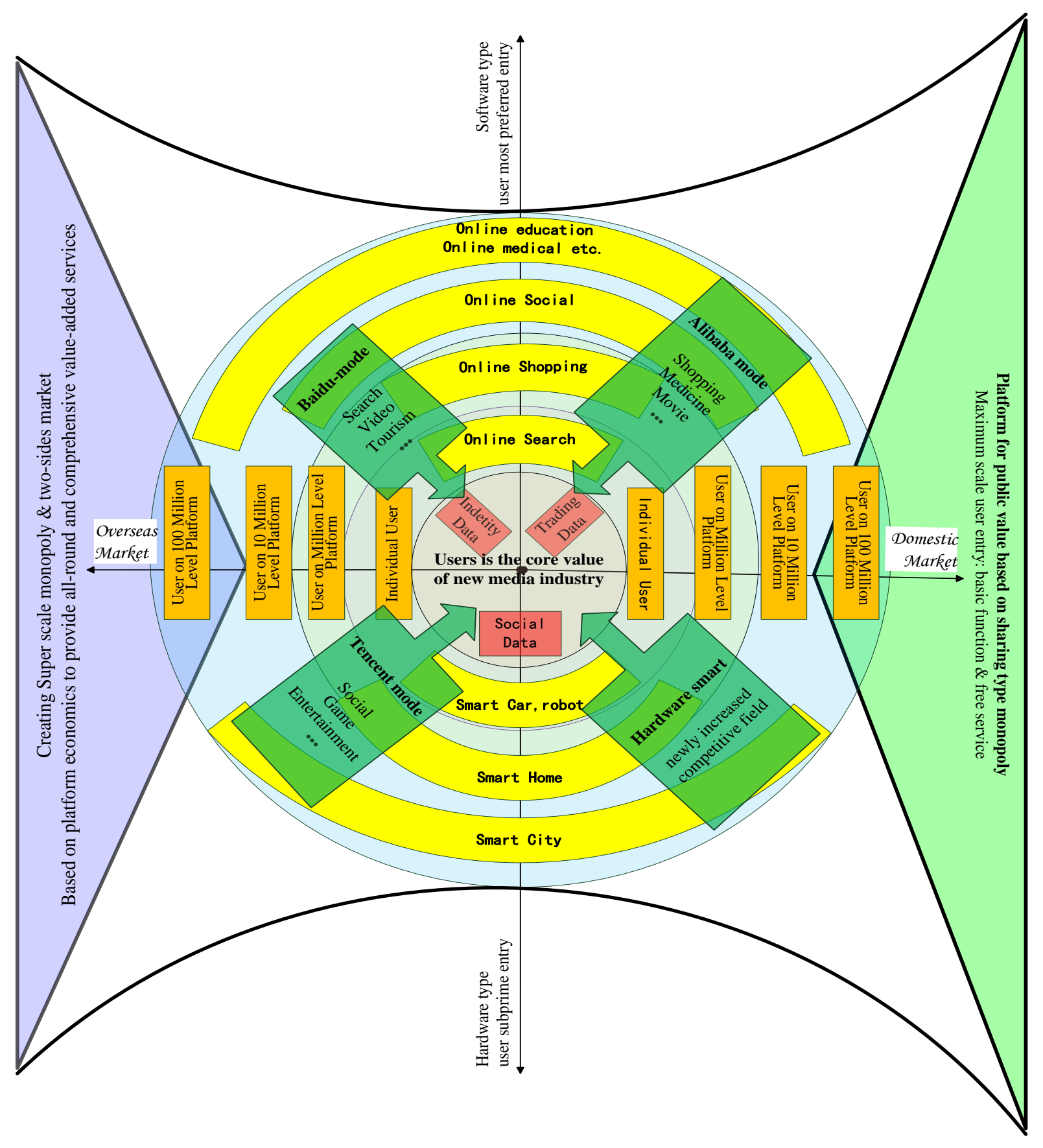


In Table 3 we can observe the highly consistent between China's new media industry and the global new media industry.

Four dark green rectangular arrows on picture above represent respectively Baidu who focuses on "search and video", Ali who focuses on "shopping and health", Tencent who focuses on "social and entertainment" and BAT as the main body plus other new media companies who focuses on smart hardware especially smart car, smart robot, smart home and smart city as secondary user entry. They are a kind of competitive cooperation relationship.

This article will give a brief analysis of numerous other rising stars outside of BAT those reaching a certain level according to the indexes of user scale, traffic scale and transaction scale.

\section{The SCP Analysis of China's New Media Industry}

According to the above definition, value connotation analysis and systematic classification of new media industry and the indexes of user scale, traffic scale and trade volume three indicators, we select the top 20 listed companies as samples from the overlap area of China's top 100 enterprises and the media sector of China's capital markets, and divided them into five categories as platform type, digital content type, network operations type, intelligent hardware type and value-added service type. It help us to tell the main structure, behavior characteristics and the performance of China's new media industry by thorough system analysis, and to give strategic suggestions accordance those system analysis.

Among the selected samples, the platform type and digital content type enterprises are the main body occupying $60 \%$, the intelligent hardware type enterprises occupies $10 \%$, the network operations type and value-added service type occupy $15 \%$ each. The all 7 platform type enterprises are listed in the US, but they began to start the privatization process since 2015 and plan to return to China's capital market.

Since Chinese capital market promoted market-oriented reform root and branch in 2015, the overseas-listed Chinese firms on US capital markets have been trying to come back to home market through back-door listing, new three boards and IPO. Most of them are internet enterprises. According to "securities daily" statistics, since 2015, there are 32 overseas-listed Chinese firms on US capital markets had received buyout offer, the total number beyond the sum during 2010 to 2014. Transaction amount is \$31 billion of dollars. Qihoo 360 co. takes nearly a third of the total amount of the transaction. In the wave of this privatization, the platform type enterprises strengthened the strategic investments and the cross-shareholdings between giants. It will reinforce the Matthew effect in larger scale (that is, the stronger the strong).

As an example, the first overseas-listed Chinese film and television company "Bona Film Group Limi" on the Nasdaq, US capital market, declared their privatization deal on December 15, 2015 and plan to complete the privatization process in the second quarter of 2016. By the end of year 2016, Bona will be listed on home A share market .In the privatization transactions, Ali Pictures co. paid \$86 million of dollars to get $10 \%$ stake of Bona Film.Meanwhile, Tencent acquired 7\% stake of Bona Film. They both are members of giant BAT of China's new media industry already.

Another typical case is Qihoo 360. So far as the biggest Chinese companies announced delisting from the United States capital market, its buyers consortium includes Taikang Life Insurance, Ping An Insurance, SUNSHINE INSURANCE, New China Capital, Sequoia Capital China, Huasheng Capital and etc. They are all famous and powerful insurance companies and venture Capital companies. In addition, there is CITIC Guoan, a Chinese giant enterprise of cable television network and satellite communications industry.

This article selects "total assets growth" and "intangible asset growth" as the core quantitative indexes on indicators, because the new media industry is a typical platform and light asset industry. The first premise of existence and development is the continuous growth of their social value and other intangible assets. At the same time, by observing the growth of the total assets, we can deeply understand their market size and their abilities to maintain the reasonable proportion of light asset by $\mathrm{R} \& \mathrm{D}$ and talent training. This ability is particularly important for Chinese new media enterprises for their too short life cycle. And this is largely due to China's new media enterprises won't pay as much attention to enterprise culture and the social value as the new media enterprises of Europe, America, Japan and South Korea. It has become the main soft spot of China's new media industry. Aiming at this reality, this article increases the 'net profit growth rate' index for A-share companies to make more direct judgment for their current living situation and the ability to develop future market. 
Table 4. Summary of new media listed enterprises in year 2015

\begin{tabular}{|c|c|c|c|c|c|}
\hline Category & $\begin{array}{c}\text { Overseas } \\
\text { Listed Company }\end{array}$ & Main Business Scope & $\begin{array}{c}\text { Gross } \\
\text { Assets } \\
\text { Growth } \\
(\%) \\
\end{array}$ & $\begin{array}{l}\text { Intangible } \\
\text { Assets } \\
\text { Growth } \\
(\%) \\
\end{array}$ & \\
\hline \multirow{7}{*}{$\begin{array}{l}\text { Platform } \\
\text { Type } \\
\text { New media } \\
\text { company }\end{array}$} & Tencent & $\begin{array}{c}\text { Chinese largest comprehensive } \\
\text { internet service provider }\end{array}$ & 144.76 & 245.81 & \\
\hline & Baidu & $\begin{array}{c}\text { The world's largest Chinese } \\
\text { search engine }\end{array}$ & 136.61 & 104.46 & \\
\hline & BABA & $\begin{array}{l}\text { Online shopping and other } \\
\text { diversified Internet business }\end{array}$ & 174.98 & 104.24 & \\
\hline & Sina & $\begin{array}{l}\text { Internet and mobile security } \\
\text { products and services }\end{array}$ & 108.66 & $\begin{array}{c}\text { Not available } \\
\text { (Pre-losing) }\end{array}$ & \\
\hline & QIHU360 & $\begin{array}{c}\text { network media companies in the } \\
\text { global Chinese community }\end{array}$ & 175.59 & 181.24 & \\
\hline & Sohu & $\begin{array}{c}\text { communications and mobile } \\
\text { value-added services }\end{array}$ & 105.86 & -49.11 & \\
\hline & NetEast & $\begin{array}{c}\text { Internet applications and other } \\
\text { technology development }\end{array}$ & 130.81 & 288.57 & \\
\hline Category & $\begin{array}{c}\text { Domestic } \\
\text { Listed Company }\end{array}$ & Main Business Scope & $\begin{array}{c}\text { Gross } \\
\text { Assets } \\
\text { Growth } \\
(\%) \\
\end{array}$ & $\begin{array}{l}\text { Intangible } \\
\text { Assets } \\
\text { Growth } \\
(\%) \\
\end{array}$ & $\begin{array}{c}\text { Net } \\
\text { Profit } \\
\text { Growth } \\
(\%) \\
\end{array}$ \\
\hline \multirow{5}{*}{$\begin{array}{c}\text { Digital } \\
\text { content } \\
\text { Type } \\
\text { New media } \\
\text { company }\end{array}$} & $\begin{array}{c}\text { Jiangsu Phoenix Publishing } \\
\text { \& Media Corporation } \\
\text { Limited } \\
\end{array}$ & $\begin{array}{l}\text { The largest china's publishing } \\
\text { companies in China }\end{array}$ & 109.32 & 120.19 & 107.27 \\
\hline & Huayi Bros. Media Group & $\begin{array}{c}\text { Comprehensive private } \\
\text { entertainment group }\end{array}$ & 171.18 & 1900.31 & 134.99 \\
\hline & $\begin{array}{c}\text { ZheJiang Daily Media Group } \\
\text { Co. }\end{array}$ & $\begin{array}{c}\text { business advertising, telecom } \\
\text { value-added business technology } \\
\text { development, }\end{array}$ & 105.54 & 113.19 & -2.60 \\
\hline & People's network & $\begin{array}{c}\text { online information interaction } \\
\text { platform }\end{array}$ & 108.63 & -11.58 & -17.81 \\
\hline & $\begin{array}{l}\text { SHANGHAIXINHUA } \\
\text { MEDIA CO. }\end{array}$ & $\begin{array}{l}\text { Comprehensive media such as } \\
\text { books, advertising, distribution } \\
\text { companies }\end{array}$ & -28.78 & -4.63 & 193.85 \\
\hline \multirow{2}{*}{$\begin{array}{c}\text { Smart } \\
\text { hardware } \\
\text { Type } \\
\text { New media } \\
\text { company }\end{array}$} & $\begin{array}{c}\text { Leshi Internet } \\
\text { Information \& } \\
\text { Technology Corp } \\
\end{array}$ & $\begin{array}{l}\text { Cross-platform network video } \\
\text { field service providers }\end{array}$ & 183.77 & 133.21 & 172.84 \\
\hline & Chengdu B-ray Media Co. & $\begin{array}{c}\text { Information dissemination } \\
\text { services, high-tech product } \\
\text { development }\end{array}$ & -4.59 & -35.97 & -51.59 \\
\hline \multirow{3}{*}{$\begin{array}{c}\text { Network } \\
\text { operation } \\
\text { Type } \\
\text { New media } \\
\text { company }\end{array}$} & $\begin{array}{c}\text { Shanghai Oriental Pearl New } \\
\text { Media Co } \\
\end{array}$ & $\begin{array}{c}\text { Digital media platform } \\
\text { development and construction }\end{array}$ & 139.59 & -1.19 & 162.35 \\
\hline & $\begin{array}{l}\text { CITIC Guoan Information } \\
\text { Industry Co. }\end{array}$ & $\begin{array}{c}\text { advertising, satellite } \\
\text { communications engineering, } \\
\text { computer engineering, cable } \\
\text { television network information } \\
\text { transmission network, mobile } \\
\text { communication technology } \\
\text { development and services }\end{array}$ & -20.63 & -84.02 & 267.60 \\
\hline & Wasu Media Holding Co. & $\begin{array}{l}\text { Cable TV, digital TV network } \\
\text { and digital communication } \\
\text { industry, the Internet information } \\
\text { services }\end{array}$ & 232.63 & 100.57 & 167.23 \\
\hline \multirow{3}{*}{$\begin{array}{l}\text { Value-added } \\
\text { Type } \\
\text { New media } \\
\text { company }\end{array}$} & $\begin{array}{l}\text { Bluefocus Communication } \\
\text { Group Co. }\end{array}$ & $\begin{array}{l}\text { Brand communication and } \\
\text { marketing, crisis management, } \\
\text { information consulting }\end{array}$ & 202.85 & 226.46 & -61.08 \\
\hline & Simei Media Co. & $\begin{array}{l}\text { Advertising agencies and design, } \\
\text { corporate image planning, } \\
\text { market research and information } \\
\text { consulting services }\end{array}$ & 112.0 & -7.96 & 148.97 \\
\hline & $\begin{array}{c}\text { Beijing Tensyn Digital } \\
\text { Marketing Technology Joint } \\
\text { Stock Company } \\
\end{array}$ & $\begin{array}{l}\text { computer systems and software } \\
\text { applications services and } \\
\text { information consultation }\end{array}$ & 141.51 & -89.25 & 149.95 \\
\hline
\end{tabular}


Because all the platform enterprises above are listed overseas, it is hard to analyze them parallel with the sample enterprises of China's new media industry. Therefore, this report will selectively focus on qualitative structural analysis as the core but not focus on the operating data analysis, and try to give a strategic summary of the development trend of new media industry through those listed companies based on the relevant data during financial year 2014 to 2015 .

The data above shows that who has better growth of intangible assets who has better market performance also. Platform type enterprises are generally performed well, with the exception of Sohu [note: Sohu becoming an exception largely duos to the platform strategy defeat of CYOU, a subsidiary corporation of Sohu. Among the A-share companies, Huayi Brothers, Le TV, Jiangsu Phoenix Publishing \& Media Corporation Limited and Bluefocus did well. But Citic Guoan, B-ray Media Co. and People's Network did relatively poor. Of course, we need to rule out the abnormal effects to indexes because of important mergers, acquisitions and investment actions.

Overall, the strategic development trends are briefly stated as follows:

First, the strategic mergers and acquisitions bring China's new media industry to the key developing period of survival of the fittest. The strategic direction in 2015 is large scale of mergers and acquisitions in $\mathrm{O} 2 \mathrm{O}$ niche markets which aim to complete new media platform transformation from "traffic-platform" to "user-platform". It will help to expand the scale of user entry and to strengthen the stability of users' platform. Typical events include the merger of Didi taxi and Kuaidadi, 58 City's investment to Ganjicom, cooperation between Meituan and Dianpingcom, equity replacement between Ctrip and Qunar, etc.

Second, Platform type new media enterprises headed by BAT still occupy the absolute dominant position. But Baidu, Ali and Tencent each has different emphasis on $\mathrm{O} 2 \mathrm{O}$ niche markets through mergers and acquisitions or internal capital injection.

Third, the content type enterprise is still in the stage of "defend the territory of their country". They need try more hard to develop their strategy of "going out". Otherwise, their market value and market share will be further behind than the platform type enterprises' even they develop themselves by larger scale of strategic mergers and acquisitions of similar companies.

Fourth, the strategic transformation of content type of the new media enterprises has achieved initial success. The private enterprises' growth of market value and brand value are better than the state-owned ones' [2].

Fifth, intelligent hardware enterprises don't have the same competitive advantage as their rivals in Europe and the United States because they are still in the stage of exploration with high risk, their core products are not outstanding enough and their market positioning is not clear enough either;

Sixth, network operation type enterprises are in the stage of steady development but lack of competitive advantage in market scale and technology R\&D [3]. They need increase input to intelligent technology like big data mining and video search [4];

\section{Comprehensive Platform: the First "Behavior-structure" Change of China's New Media Industry}

The term comprehensive platform has two major connotations. First is to point to strategic transformation of platform-based enterprises from developing simplex and super scale monopoly user entry to new comprehensive user entry fitted for $\mathrm{O} 2 \mathrm{O}$, combination of software and hardware, artificial intelligence and etc. Second is point to strategic transformation of non-platform-based SME (small and medium-sized enterprises) from creating web portal to developing the segment markets which highly complementary or quite different with platform-based enterprises [5].

According to the data of "China's Internet Enterprise Top 100" ranking list in 2015 issued by ISC (the Internet society of China) and MIITIC ( the Ministry of Industry and Information Technology Information Center) jointly on July 15, 2015 in Beijing, the internet business revenue of those top 100 enterprises reached 573.5 billion yuan and accounted for $20.5 \%$ of the total amount of China's information consumption in 2014. Their year-on-year growth of overall revenue is $47 \%$, contributing $7.7 \%$ growth to information consumption and $42.3 \%$ to information consumption increment. Their industry formats are very diversified and rich covering e-commerce, portal, internet finance, online game and online video.

\subsection{The Inherent Law and Analysis Framework of Comprehensive Platform}

For the interactive communication mode of social platform is most various and abundant, we take WeChat as typical example and extract four transmitters such as independent user (customer), friend group, business organization and society(including the public and the government). Based on it, we structure the following $4 \times 4$ matrix with 16 interactive communication modes. When we fill the survey data of users' preferences for different interactive communication mode with simple average, we got the following data Table which showing the changing path of inner structure and inherent law of user preferences. 
Table 5. The matrix of interactive modes online and changing path of user preference

\begin{tabular}{|l|lc|ll|ll|ll|}
\hline Transmitter/ Preference(P) & C & P & G & P & B & Pref & S & P \\
\hline C(Customer) & C2C & 012 & C2G & 84.6 & C2B & 82.3 & C2S & 78.8 \\
\hline G(Group) & G2C & 78.7 & B2G & 696 & G2B & 57.2 & G2S & 53.3 \\
\hline B(Business) & B2C & 51.5 & B2G & 50.9 & B2B & 504 & B2S & 48.9 \\
\hline S(society) & S2C & 45.6 & S2G & 40.1 & S2B & 22.5 & S2S & 186 \\
\hline
\end{tabular}

We can clearly observe the user preferences changing path going from the upper left $\mathrm{C} 2 \mathrm{C}$ mode and down to the lower right S2S mode. It also represents the tendency of network users and network traffic. That means network user and traffic will further gather to the $\mathrm{C} 2 \mathrm{C}$ mode and any other mode dominated by user power. So we can also see the large difficulties and barriers who will have if they want to develop $\mathrm{C} 2 \mathrm{C}$ mode based on $\mathrm{B} 2 \mathrm{C}$ or $\mathrm{C} 2 \mathrm{~B}$ mode adversely.

The changing path above also revealed at least two facts and trend worthy our attention:

First, in the digital network taking point-to-point transmission as its core, the user's personal intention decides the evolution direction of communication mode. At the present stage, the intention of individual user and market tend to be more consistent. It suggests that individual users will be more willing to assign their own private space to public space, to form a larger integration field of public and private which continues to expand.

Second, individuals, groups, market and government will follow the changing path of user preferences to develop $\mathrm{C} 2 \mathrm{C}$ mode no matter what mode they based on now. It's no doubt C2C mode will be further strengthened[6].

This means comprehensive platform based on social, shopping or search has different efficiency and prospects according to their distance to $\mathrm{C} 2 \mathrm{C}$ mode [7]. It is more closer, it will be more efficient and prospective. In other words, social platform based on $\mathrm{C} 2 \mathrm{C}$ mode directly is most advantage [8].

It is proved already. Globally, the fastest developing comprehensive platforms have the largest user scale[9]. In China, is WeChat and in the United States is Facebook.

Then, we will observe and analyze the BAT each demonstration according to their distance to $\mathrm{C} 2 \mathrm{C}$ mode[10].They create the different path to develop comprehensive platform for China's new media industry, respectively based on the social, shopping and search, which promote the sustainable development rooted on content innovation[11].

\subsubsection{Tencent: Comprehensive Platform Based on Social and Entertainment}

Tencent has a strong business group of network media: Tencent website is comprehensive portal website integrating news and information, social media information and products, as well as regional vertical life services. Tencent news client connected to share market and game playing platform as a wireless information product matrix, creates the experience of convenient services for users with zero distance access to any information at anytime and anywhere. It represents a new generation of network media platform real-time, custom-made and professional. [12]

Data from various mobile video terminals shows that $85 \%$ of Chinese users like to see long video with mobile clients. Among those long videos, TV play, film and variety show account more than 70\%.This makes the self-produced TV play become new bright value-added spot and contributes to online payment business growing a lot.

QQlive is China's largest online video platform. It is going to update itself to a new entertainment platform with most internet characteristics by integrating Tencent's unique mobile service and social products.

In addition, Tencent has abundant commercial media formats such as QQ mailbox, Tencent Games, Tencent Literature and Tencent Animation. [13]

\subsubsection{Ali: Comprehensive Platform Based on Online Shopping, Internet Financial and Content Industry}

Alibaba's comprehensive platform includes Taobao, Tmall, Juhuasan, Aliexpress, Alibaba International Trading Market, 1688, Ali Mother, Ali Cloud, MYbank, Cainiao, etc. According to U.S. media reports, Ali's annual revenue in 2015 reached RMB 103.5 billion. The growth rate is lower than $48 \%$ as forecast in 2014. But according to the quarterly report in 2015, Ali's MAU (monthly active user) on mobile platform got annual growth rate of $138.5 \%$, and income of mobile platform increased by $1020 \%$.

Ali's mergers and acquisitions in 2015 highly associated with media industry. It covers lots of China's first-class content media company such as the Beijing Youth Daily, the South China Morning Post, China Business Network, Enlight Media, Huayi and China Vision Media Group. It also involves lots of important network new media company such as Sina Weibo, Huxiu, Youku Tudou and etc. We can see the strategic investment intention and results to reform the traditional media industry through large scale integration of high quality assets of content industry and new media platform.[14]

Ali's media industry investment above covers lots of China's first-class content media company such as the Beijing Youth Daily, the South China Morning Post, China Business Network, Enlight Media, Huayi and China Vision Media Group. It also involves lots of important network new media company such as Sina Weibo, Huxiu, Youku Tudou 
and etc. We can see the strategic investment intention and results to reform the traditional media industry through large scale integration of high quality assets of content industry and new media platform.

For these purpose, Ali launched its international acquisitions based on online shopping.

On February 12, 2016, Ali signed strategic cooperation agreement on with S.M. Entertainment to develop music business and e-commerce business in China. Alibaba Group and Alibaba Music Group will help SM with online music sales, marketing and product planning in China. It will generate coordination effect in many areas.

This report will continue to analyze Ali's international strategy layout later.

Table 6. General situation of Ali's investments in media industry

\begin{tabular}{|c|c|c|c|c|}
\hline Collaborative Agents & $\begin{array}{c}\text { Investment } \\
\text { Time }\end{array}$ & Amount & $\begin{array}{l}\text { Investment } \\
\text { Proportion }\end{array}$ & Media Form \\
\hline Taobao World, Zhejiang daily group & $2009-4$ & unknown & unknown & magazine \\
\hline Iwshang, Zhejiang publishing united group & $2010-4$ & unknown & unknown & magazine \\
\hline Sina microblog & 2013-2014 & $\$ 0.59$ Billion & $32 \%$ & $\begin{array}{l}\text { Social } \\
\text { media }\end{array}$ \\
\hline Business Review Weekly & 2013-4 & unknown & unknown & Finance Media \\
\hline Culture China & 2014-3 & $\begin{array}{c}\text { HK\$ } 6.2 \\
\text { Billion }\end{array}$ & $60 \%$ & $\begin{array}{c}\text { Entertainment } \\
\text { media }\end{array}$ \\
\hline Wasu Media & $2014-4$ & $\begin{array}{c}¥ 0.5 \\
\text { Billion } \\
\end{array}$ & $20 \%$ & Culture industry \\
\hline Huxiu & $2014-5$ & $\begin{array}{l}¥ 24.84 \\
\text { Million }\end{array}$ & $15 \%$ & $\begin{array}{c}\text { Technology } \\
\text { media }\end{array}$ \\
\hline Huayi Bros. Media Group & 2013-2015 & $>\$ 1.5$ Billion & $8.06 \%$ & $\begin{array}{l}\text { Entertainment } \\
\text { media }\end{array}$ \\
\hline Enlight Media & 2015-3 & $\begin{array}{l}2.4 \\
\text { Billion } \\
\end{array}$ & About $20 \%$ & $\begin{array}{c}\text { Entertainment } \\
\text { media }\end{array}$ \\
\hline China Business Network Co.,Ltd. & $2015-5$ & $\begin{array}{l}¥ 102 \\
\text { Billion }\end{array}$ & $30 \%$ & Finance Media \\
\hline Community paper of Beijing youth newspaper Group & $2015-5$ & unknown & unknown & Public media \\
\hline Unbounded news & 2015-9 & unknown & unknown & Mobile media \\
\hline $36 \mathrm{kr}$ & 2015-10 & \$0.1 Billion & unknown & $\begin{array}{c}\text { Technology } \\
\text { media }\end{array}$ \\
\hline Cover Media, Sichuan newspaper group & $2015-10$ & unknown & unknown & Public media \\
\hline Youku Tudou Inc. & $2015-10$ & \$4.5 Billion & buyout & Online video \\
\hline South China Morning Post & $2015-12$ & unknown & unknown & HK media \\
\hline
\end{tabular}

Source: Sina blog 353 north latitude 


\subsubsection{Baidu: Comprehensive Platform Based on Online Search and Artificial Intelligence}

Baidu is trying hard to integrate its search, maps, and service trade to develop and improve its comprehensive platform further.

In May 2015, Baidu opened the world's largest distributed deep machine learning open source platform officially to public. This platform provides a unified script to compile and run all of the components so the application developers can get free access to distributed machine learning algorithm source code, in order to reduce the threshold ad cost of development and deployment of distributed machine learning system and related application work. [15]

It is worth mentioned that the main business of Baidu is online search, so Baidu strategically need to develop large-scale closed-loop consumption data in order to further expand the comprehensive platform [16].

\subsubsection{Wonderful View of Comprehensive Platform outside BAT}

Although so many landmarks and macro trends of China's new media industry are established by BAT, but the world outside BAT is wonderful too.

These wonderful are divided into two parts:

One part is about construction of new platform with support of intelligent hardware and virtual reality technology. Such wonderful stories are rare and commendable.

Another part is about small innovative companies. The author will detail them later in the next section.

In 2016, the core technology of new media is artificial intelligence, mainly including the identification of complex information such as video and text, virtual reality, machine learning, emotion perception, dynamic pricing and telepathy, etc. Among them, machine learning technology will do the greatest transformation work on media industry. It not only will gradually replace the formatted news writing work, but also replace analytical, research and explanatory news writing work after combined with big data and cloud computing technology in the future.

First of all, in the next 2-3 years from 2015, all kinds of intelligent hardware related to information collection and information dissemination will rapidly develop such as small intelligent hand ring or big smart car. The foreground is wide and broad. And the whole picture of new media industry will be further restructured.

Second, 2016 will be the first year of virtual reality (VR) era. Some agencies predicted that the shipments of global VR equipment would be more than 5 million in 2016 and would reach 3000 million in 2020. The corresponding market scale is more than $\$ 150$ billion. Facebook, Google, Samsung, Tencent and other technology giants have announced their plans to enter the field of VR, aiming the huge development space.

On China's capital market, there are many enterprises related to VR technology like LingNan Landscape Co.,
Hangzhou Shunwang Technology Co. and etc.

In addition, there are many new star companies outside BAT like MI on wearable equipment platforms, Le TV and Cool clouds on smart TV platform, and lots of small and medium-sized enterprises on smart car platform. They are likely to become very important platform type enterprises besides BAT in China.

\section{(1) Wearable Devices}

There are two optimized options for China's wearable device companies to achieve industrialization:

One is sports and health care, represented by intelligent hand ring and intelligent watch.

Second is entertainment online social. There are no any mature products with clear position and perfect function. Google glasses can only be said as a good try but hasn't succeeded yet.

Tic watch, inWatch and other smart watch companies in China have started using TOS dedicated operating system launched by Tencent and giving up mobile phone operating system with simple change.

The second generation of MI's bracelet has been able to monitor the user's heart rate. Beijing Millet technology co., LTD was established in April 2010 and it always focused on intelligent product through independent research and development as a mobile internet company. Its pioneering mobile phone operating system developed a new platform-customized-mode to attract enthusiasts to participate in its products improvement and strategic development.

During 2015, MI successively launched its intelligent mobile phone series Red MI, Mi Wifi, Mi air purifier, Mi bracelet and Mi water purifiers, etc. On January 15, 2016, Lei Jun, CEO of MI, announced at the annual meeting that the MI laboratory will be set up and focus on virtual reality (VR) and intelligent robot as new direction to lay the foundation for further development.

\section{(2) Smart TV}

In the field of Chinese smart TV, a number of innovative companies worthy awe emerged like Whaley technology Co., Le TV, MI and Windstorm Image Sound and Cool Clouds, etc. Their core products focused on the television screen platform, precision advertising platform, data platform and multi-screen interactive platform, etc.

Table 7. Smart TV new Internet company

\begin{tabular}{|c|c|}
\hline New Type Company & New products \\
\hline Whaley technology Co. & Launched The first generation of smart TV \\
\hline Le TV & Launched two new smart TV \\
\hline MI & $\begin{array}{c}\text { Launched The third generation TV box, } \\
\text { two new smart TV and new TV host }\end{array}$ \\
\hline Storm Player & Launched three new IPTV \\
\hline
\end{tabular}


Table 8. Internet transformation of traditional TV makers

\begin{tabular}{|c|c|}
\hline $\begin{array}{c}\text { Traditional TV } \\
\text { Company }\end{array}$ & New media investment and business \\
\hline TCL & Jointly set up OTT company to raise internet \\
capital
\end{tabular}

Table 9. Technology and content of the comprehensive fusion

\begin{tabular}{|c|c|}
\hline $\begin{array}{l}\text { Hardware } \\
\text { Company }\end{array}$ & Content expanding \\
\hline MI & $\begin{array}{l}\text { Invest Youku Tudou Inc and jointly set up 'New } \\
\text { Saint Picture Co.' with Huayi Bros. Media Group }\end{array}$ \\
\hline Le TV & $\begin{array}{c}\text { Buy live right of UEFA Champions League and } \\
\text { Spain's La Liga } \\
\end{array}$ \\
\hline Ali & Launched TBO paid streaming media service \\
\hline
\end{tabular}

Overall, OTT (over the top) has become the mature basic framework of network platform for smart TV. Settled on this basis, the three strategic focuses for smart TV in 2016 are more personalized content production, more high-tech video games and more scenario-based online shopping.

\section{(3) Self-driving Car}

Although BAT had set up their smart car departments or companies, but the real success at present is Le TV who has attracted world's attention. It is building a new smart car platform aiming the first independent research and development car of China and settled its first production base in Frankfurt, Germany.

In January 2015, Le TV super car (China) company was established in Beijing, released LeUI Auto version of smart car, its first completely independent research and development smart car and "SEE plan". This smart car with advanced intelligent voice recognition function make cars easily understand the needs of users by full voice control system. In the near future, smart vehicle-mounted system will be the driver's personal assistant to realize interaction between car and car, car and road, car and people, car and other intelligent terminals making the car more smart. On the intelligent platform of LeUI Auto version of smart car, the driver can remotely manage and control the smart car on smart phone or smart TV. This car will be sold globally in the future.

In addition, the smart car is a mobile entertainment media with online music, internet radio, local music, and FM radio. It also provides rich original video library resources of Le TV more than 5000 movies and 100000 TV episodes. Those online content are connected to user's mobile phone TV by cloud synchronization so that user can continue to watch any content on all kinds of terminals.

\section{(4) Unmanned Aerial Vehicle (UAV)}

The application space of unmanned aerial vehicle (UAV) is very broad from wireless network infrastructure, smart courier to aerial image information collection. It has been the pioneers of air intelligence world.

Year 2015 to 2016 will be the initiative performance period of unmanned aerial vehicle (UAV) to develop platform, two-side market demand and business mode which penetrates media industry quickly and roundly.

The innovation enterprises below represent the future of China's unmanned aerial vehicle (UAV) industry.

Table 10. Innovative UAV enterprises in China

\begin{tabular}{|l|l|}
\multicolumn{1}{|c|}{$\begin{array}{c}\text { UAV } \\
\text { Startups } \\
\text { nJI-Innovatio } \\
\text { ns }\end{array}$} & \multicolumn{1}{|c|}{ Core technology } \\
\hline ZEROTECH & Flight Control \\
\hline ProDrone & $\begin{array}{l}\text { UAV folding technique, modularization, UAV } \\
\text { infrared ray }\end{array}$ \\
\hline Ehang & No lead-edge technologies but easy operation \\
\hline Tuneec & Manned flight, Equipment FPV, radio control \\
\hline Hikvision & Industrial-grade UAV, security and protection \\
\hline XAIRCRAFT & Agricultural plant protection \\
\hline Ewatt & power line inspection \\
\hline
\end{tabular}

source: http://www.useit.com.cn

\section{(5) Internet Insurance}

The internet insurance, similar with internet finance, pays attention to data, scene and disinter-mediation. BAT dominates China's internet finance but hasn't done the same to internet insurance. They want further development. In June 2015, Zhongan insurance Co. ranked only after Ant Financial gold with 50 billion yuan valuation and nearly 6 billion yuan financing. Zhongan insurance Co. is tightly attached to many platform type new media companies providing innovative insurance like Meituan food security liability insurance, Helijia reassuring security risks, tire accident insurance, gene known insurance, Taobao occurrences of risks, Zhonglebao insurance and other innovative products as new type of insurance service for internet ecology. Gene known insurance, based on the accurate medicine, is the first China's internet insurance of genetic testing launched by Zhongan and its partner Complete Genomics. It is likely to be a new media medical platform.

\section{Small Micro Content Forming Huge Long Tail: Second "Behavior-Structure" Change of China's New Media Industry}

Developing comprehensive platform can't only rely on technology innovation. So around 2015 headed by BAT, new media companies invested content industry heavily or cooperated with content industry strategically in long-term [17]. The try to be new giant strong with software, hardware and content produce in the path of content is King. Meanwhile, as mentioned above, small micro content innovative companies emerge one after another and grow into a huge "long tail".[18] 


\subsection{Small Micro Content Creates Huge "Long Tail"}

Content innovation supported by small micro companies is forming a huge "long tail" of new media content as king. It is the inevitable developing trend of we-media in the mature period of new media. [19]To integrate the "long tail" of content with the "long tail" of technology and market will bring new power for the next industrial structure adjustment. We could call it "rising of small micro power" which represents the future of China's internet new media and fully restructure content distribution and transmission channel.

\subsection{Internationalization Layout: Third \\ "Behavior-structure" Change of China's New Media Industry}

Headed by Baidu, Tencent and Ali, platform type enterprises rapidly expand diversified investments, involved directly in the upgrade process of China's products and services [20]. At the same time they expand overseas consumer market to accelerate the process of strategic internationalization layout. [21]

This is a very difficult strategy process. Tencent's internationalization layout by WeChat, beginning around 2011, hasn't been successful yet. [22]

There are two reasons:

First, China's new media companies are lack of attractive corporation culture.

Second, the market environment differences and institutional environment differences caused the adaptability differences to international market of China's new media products enterprises and their products, such as fake filling in online malls, rampant plagiarism and copying, quick success operating management idea, etc.

\section{Management Strategy Advice for China's Internet Media Industry}

All facts and trends about the speeding expansion of comprehensive internet media platform reflect that the worldwide digital network lacks proper grass-roots management framework and multi-win interest coordination mechanism. For example, for users who create and nourish such network community, their fundamental interests are not well governed and protected all the time. There is an evident proof: there is no definition of network privacy. Nobody can seize such area arbitrarily. Thus, the base of network governance is instable, to some extent, barely not, which gradually becomes the threaten to the network economy and safety protection. Hence, public opinions of the bottom class of the society, especially related to the field of interest of people's livelihood, usually have anti-mainstream and anti-traditional characteristics, with a lot of incidents caused by risk of boiling over. Moreover, contradictions between grassroots and authorities, public and government are likely to cause fiercer social instability.
Since completely digital society not only gives the good motive powers, but also stronger ones to the evil. So given enough time, everything will be located in a mess.

\subsection{Management Strategy Advice for China's Internet Media Industry Structure Optimization}

The fundamental strategic approach to solve this hidden danger lies in reexamining the interest relationship and benefit distribution pattern among network users, enterprises or non-profit institutions and governments in the new media society, gradually perfecting the protection mechanism for network users' interests, comprehensively enhancing social function of the network users, and transforming dual-corporation or nonprofit organization and government-governance model into a more stable, lasting ternary-user consortium, corporation or nonprofit organization and government-governance model as soon as possible. As a result, we need to unite highly fragmented global users innovatively together to form a new legal entity with integrated mobility to practically protect individual privacy and related interests, thereby consolidating the basic governance structure of the entire network society and better balancing the interests of all parties can be important to achieve a new dynamic balance. Those who can take the lead in the construction of such a dynamic balance will be able to transcend national boundaries across the globe, win hearts and minds of people, and become a borderless network power.

However, at present, government and for-profit enterprises, as the protector of personal privacy of the users, are often difficult to transcend secular interests. With the identity of administrators and its convenience, they often become target suspects on stealing personal privacy information and in fact the doers. Thus, the dual governance model of government and enterprises is not suitable to serve as the core model of Internet privacy protection and security governance. The real focus should be the global Internet users after effective integration, an innovative behavioral subject with highly collaborativity and integrated mobility. This requires not only sufficient judgment, insight and courage to practice, but also a high degree of rationality, a deep understanding of human nature, and respect to make every people, in dealing with their relationship with new technology, have the necessary right to determine and select what good technology and good products are suitable for them, which will inject human nature into new technology, with force for good guiding and ruling the development of technology and new media society.

Before the implementation of the innovative practices mentioned above, two important realistic premises are required :

First, personal privacy information should be of value and legally protected, that is, explicitly stated as an information asset.

Second, every web user should be reasonably empowered 
with the necessary incremental human rights, that is, to give every user an opportunity to participate in determining the relationship between themselves and the new technology.

Thus, the concept of "technical human rights" is put forward, its basic connotation is summarized as follows:

First, the full right to choose. For any new technology product or function that involves the acquisition of personal privacy information, users should have the right to choose whether to accept or reject it. In other words, if users are not sure whether to accept a particular new technology product or function, they are free to choose not to use it without any real or potential loss. For example, if a user refuses to let the operator obtain his or her location information, he or she would not be able to use the basic service provided by the operator, which is not suitable.

Second, the reasonable right to delete. For those online information that is detrimental to the privacy of individuals or to their information assets, users shall have the right to make normal legal claims and to remove such information free of charge. At present, there are two feasible mechanisms of practice: one is the market-based "payment delete" mechanism, the other is a more mature "application - review - delete" mechanism. Established by Facebook, Google and other social media companies in Europe and the United States, this mechanism allow Individuals or governments to submit an application to delete the information, after reviewing, the information publisher is responsible for deleting the relevant information.

Third, the symmetrical right to know, which means users should have such authority as transaction party in any circumstances related to personal privacy, transaction and transmission activities. Recently, there are plenty of problems in this field. For example, most of the users are required to sign a tediously long user agreement the first time they download a software. However, users lack related law and technology knowledge, even if they had already read the whole agreement, they could not understand law relation of right and obligation refers to the agreement. Usually, they approve under the condition of ignorance and frustration. As a matter of fact, they need a professional lawyer, a qualified engineer and a specialized surveyor to help them make the decision. Meanwhile, some of the users are people with specialized knowledge and willingness to offer knowledge. Nonetheless, no platform can be utilized to unite the supply and the demand.

Fourth, the differentiated and individualized right to be treated, which means users should have the authority to be treated and governed as unique individual in the process of the communication and transmission of information. Of course, this is a procedure step by step, which needs the improvement in the supporting technology and the perfection of social governance framework. In other words, like the mode in the Industrial Age, the thinking and framework of network society governance sees people as identical target to serve and govern, which causes many man-made unfairness, injustice and unreasonableness. Especially in the field of network privacy and security governance, there are several irrationalities. In fact, opinions to network governance differed from person to person. Then, people can make personalized definition of confidential information independently. Thus, intelligentize governing system will conduct high-level security supervision on the information asset which is identified as "privacy", meanwhile conduct supervision which is applied to public information to the others. If our governing institution obliges everyone adopt an "one size fits all" law to define and manage privacy, it will not only run counter to the point-to-point feature to the digital network, which results in deficiency in applicability, but also be helpless to boost definition, transaction and protection of personal information asset.

Therefore, the future of network governance requires a basic idea of adjustment and innovation to offer each user with the opportunity to define and protect their privacy directly, independently and individually, and to be free to adjust, improve and manage their private information assets. At present, the seemly more practical and innovative management model is to learn from Wikipedia's all-public thinking and crowd funding, which means in such model, network users submit their personal private information to trusted open, socialized public information platform to actively submit personal privacy information. And in the the process of submission, according to their needs and understanding, personalized information to define their own assets to make clear what kind of personal privacy to become public information assets, while the rest of the private information is accordingly classified as non-public personal assets. Once classified as personal information assets, on one hand, no one is free to infringe on, on the other hand, it can be directly refered to physical assets in mutually beneficial transactions. In fact, it is possible to construct the concept of "technical human rights" only when the user privacy information becomes a virtual and valuable asset, and is expected to develop a truly effective and sustainable mechanism for privacy protection and network security governance framework.

From a broader perspective, socialized media platforms which had already accomplished global monopolization create platform economics and bilateral market. With such foundation, it is continually pushing and improving the corporation between various fields, surpassing the management of countries and enterprises. For this reason, we need new subjects, new thoughts and patterns to manage the Internet, where it could satisfy the complex need for privacy under the progressing Internet environment, in order to protect the sustainable development of Internet economy from this fundamental security risk.

\subsection{Management Strategy Advice for China's Internet Media Industry Operating}

- encourage developing personal data assets platform and improve digital credit society

- encourage public platform construction 
- important innovative areas need easing policy

- pay attention to emerging user entry

- Strategic investment for enterprise culture and social value

Above all, the main issue of "technical human rights" is: how to build a globalized coordinating system that based on both self-control and regulations. In order to sustainably benefit individuals, countries, and business, and form a community of interests between them, we need to change the present situation of privacy protection, where individuals, countries, and enterprises stand against each other, comprehensively protect privacy, and maintain internet security use with the faith of "serve under the people" as its top priority.

\section{REFERENCES}

[1] Jean Tirole, Jean-Charles Roche. Platform Competition in Two-Sided Markets [J]. Journal of the European Economic Association, 2003(6), 990-1029.

[2] Jean Burgess, Joshua Green.YouTube: Online Video and Participatory Culture[M]. London: Polity Press,2nd ed, 2015.

[3] Celicia Scott. Youtube: How Steve Chen Changed the Way We Watch Videos [M]. PA: Mason Crest Publishers ,2015.

[4] Jason Miles. YouTube Marketing Power: How to Use Video to Find More Prospects, Launch Your Products and Reach a Massive Audience [M]. New York: McGraw-Hill Professional, 2014.

[5] Lyle Simon. Online Video Rental: Netflix, Competitors, Variations, and Alternatives [M]. NY: Webster's Digital Services, 2011.

[6] Regan, P. M. Legislating privacy: Technology, social values, and public policy. Chapel Hill, Carolina: The University of North Carolina Press, 1995.
[7] Gillian Doyle. From Television to Multi-Platform: Less from More or More for Less? [J]. Convergence, 2010, 16(4):431-449.

[8] Thomas A. Kelleher. Public Relations Online: Lasting Concepts for Changing Media [M]. CA: SAGE Publications, Inc , 2007:106-116.

[9] Therese Tierney, The Public Space of Social Media: Connected Cultures of the Network Society [M], NY: Routledge, 2013, 99-105.

[10] Erik Qualman. Socialnomics: how social media transfer the way we live and do business [M]. Brilliance Corp, 2009.

[11] Variable and strain, the Chinese Internet annual trend report (2015-2016)

[12] EnfoDesk, China's Internet industry: 2015 development trend, 2016 developing predict

[13] iRearch: 2015 report for the annual Chinese Internet hotspot insight

[14] Millward Brown: digital and media forecast in 2016

[15] Ericsson: 10 big heat consumption trends in 2016

[16] Deloitte: "2016" science and technology, media and telecommunications industry forecast

[17] Tencent: "the media age: China's new media trends report 2015

[18] New media summit 2015 Sina: the future trend of media report

[19] The pew research center: 2015 the new media research report

[20] electric business development, China's online holiday consumption report

[21] Decryption WeChat: Tencent WeChat basic characteristics and the user behavior data report

[22] Tencent: the most detailed WeChat white paper in 2015 